Article

\title{
Enabling Socio-Ecological Resilience in the Global South: Insights from Chennai, India
}

\author{
Nilofer Tajuddin ${ }^{1}$ (D) and Marcin Dąbrowski ${ }^{2, *(\mathbb{D})}$ \\ 1 Independent Researcher, 3074EC Rotterdam, The Netherlands; nilofer.afza@gmail.com \\ 2 Department of Urbanism, Faculty of Architecture and the Built Environment, Delft University of Technology, \\ 2628BL Delft, The Netherlands \\ * Correspondence: m.m.dabrowski@tudelft.nl
}

Citation: Tajuddin, N.; Dąbrowski, M. Enabling Socio-Ecological Resilience in the Global South: Insights from Chennai, India. Sustainability 2021, 13, 10522. https://doi.org/10.3390/ su131910522

Academic Editors: Fausto Cavallaro, Francesco Musco and

Eugenio Morello

Received: 23 August 2021

Accepted: 16 September 2021

Published: 22 September 2021

Publisher's Note: MDPI stays neutral with regard to jurisdictional claims in published maps and institutional affiliations.

Copyright: (C) 2021 by the authors. Licensee MDPI, Basel, Switzerland. This article is an open access article distributed under the terms and conditions of the Creative Commons Attribution (CC BY) license (https:// creativecommons.org/licenses/by/ $4.0 /)$.

\begin{abstract}
Addressing climate change adaptation in the cities of the Global South is crucial as they are the most at risk and, arguably, the least capable of coping with it due to their rapid expansion, informal development, and limited institutional capacity. This paper explores this challenge in the case of Chennai, India, a city which, in recent years, has faced several climate related disasters, including floods. Building on an innovative combination of research methods (policy documents analysis, stakeholder interviews, and a community workshop), the study analyses the barriers and explores potentials for operationalising socio-ecological resilience in Chennai in the face of an ongoing conflict between rapid urbanisation and the natural water system, compromising the region's hydrological capacity and resilience to flooding. In particular, drawing on the notion of evolutionary resilience and multi-level approach, the paper investigates (1) the scope for developing an integrated vision for resilience of the Chennai region (macro level); (2) the presence and the capacity of institutions to connect the different stakeholders and mediate their interests (meso level); and (3) the barriers and potentials developing local adaptation strategies in a bottom-up manner (micro level). The study sheds light on the under-researched issue of socio-ecological resilience in Chennai, while identifying potentials for implementing it through a combination of top down and bottom-up approaches, which in turn provides useful lessons for planning for resilience in other cities in the Global South.
\end{abstract}

Keywords: resilience; climate change adaptation; spatial planning; flooding; India; Chennai

\section{Introduction}

Rapid population growth, unchecked urbanization, migration, economic and technological development, and social and political processes have triggered irreversible environmental changes within the urban ecosystems. These changes weaken the ability of natural and built environments to cope with climate related disasters such as flooding, heat waves, cyclones, or rising sea levels, making the growing cities, their inhabitants, assets, and infrastructure increasingly vulnerable to climate change impacts. As cities continue expanding and climate patterns continue to change, addressing the twin challenges of the mitigation of greenhouse gases emissions and adaptation to the impacts of climate change in cities has become a particularly 'urgent agenda' [1,2].This leads both to the proliferation of urban climate change policies, local innovations to mitigate climate change impacts (e.g., [3,4]), and emergence of resilience discourse and policies [5]. By the same token, there are increasing efforts to integrate measures to adapt to the impacts of climate change into urban planning processes (e.g., [6-13]), however, despite the discourse on paradigm shift that resilience brings to planning practice, in reality the changes it brings to planning remain limited to 'techno-managerial' shifts and reactive measures, as opposed to addressing the wider socio-cultural shift that is needed to improve the resilience of cities to climate change [14]. 
In the face of limitations of traditional civil engineering solutions to mitigate flood risk, nature-based solutions are increasingly put forward as a means to improve resilience, while providing a range of ecosystem services to urban dwellers, promoting well-being and liveability of urban spaces (e.g., [15]). However, while the use of nature-based solutions in planning is advocated widely, the operationalisation of this approach remains challenging [16]. Planning for resilience and the use of nature-based solutions for this purpose are inherently complex due to multiple functions that these solutions provide (e.g., blue-green infrastructures can provide water storage, urban heat island mitigation, space for recreation, and biodiversity restoration) and the multiple trade-offs involved concerning scales at which to implement them, which social groups can benefit from the services provided, temporal issues concerning the long term benefits vs. short term costs and limited time horizons of decision makers (see, e.g., $[5,17,18])$. Resilience and the use of nature-based solutions may offer a useful narrative device for policymakers and provide a 'glue' to connect different sectoral policy agendas [13], but, due to the said complexities, these innovations are rarely taken up in spatial planning and urban design practice on the ground. Moreover, the research on and the practice of planning for resilience seldom considers socio-spatial justice aspects and the need to, at least, acknowledge that resilience planning should specifically address the needs of the vulnerable and marginalised social groups [19] (p. 129). What makes this omission even more striking is that planning for climate adaptation can make socio-spatial inequalities worse by displacing the poor, by failing to ensure even access to safety produced by the infrastructures put in place, or by restricting access to decision-making processes to the elite and experts [20]. In fact, vulnerability to climate change impacts such as flood or urban heat is uneven, as it reflects the socio-spatial and economic disparities in cities, with the poorest groups inhabiting areas that are the worst equipped to mitigate those impacts, whereas urban resilience policies and discourse tend to gloss over this inequality [21].

Within the different types of urban regions around the world, delta areas are most vulnerable to the changing climate patterns [22]. In fact, they face additional risks due to their location and unique relationships with water, and have been regarded as climate change 'hotspots' [23]. While cities in deltas continue to expand, often in an uncontrollable manner, the concentration of population and economic activity tends to make them more vulnerable to climate change impacts. Consequently, the ways in which cities develop and manage their urban growth are keys to understanding how they could become resilient to climate change in the future [24].

This challenge is the most acute in deltaic urban areas in the Global South, where urbanisation is the most rapid, socio-spatial inequalities are particularly deep, and the capacity to deliver planning for resilience tends to be the lowest. Municipal governments in developing countries often tend to overlook climate adaptation and resilience altogether when steering urban development. Instead, they respond to more immediate issues such as tackling rapid population growth or stimulating economic and infrastructural development. This in turn has made these cities more exposed to risks due to the increasingly tangible effects of climate change.

Previous research has suggested that addressing climate resilience in the context of the Global South was crucial not only due to its greater vulnerability to climate change, but also due to its weaker capacity to cope with the impacts [25,26]. Hence, climate change adaptation is a crucial need of the hour, especially in urbanised deltas of the Global South; however, there is still limited knowledge on how to operationalise resilience in spatial planning in general, and in those areas especially. In the face of the abovementioned acute challenges in the cities of the Global South, to build resilience in these urban areas, one needs to consider "negotiated resilience" focusing on designing processes to bring together a diversity of interests of various stakeholders and put forward an approach that builds on endogenous, place specific processes, social norms, and local (often traditional) knowledge that can support resilience [27]. There is, however, a shortage of research exploring the barriers and potentials for facilitating this. 
This paper strives to address this gap in the literature by exploring the resilience capacity of Chennai and its region, located in Tamil Nadu in southern India. The focus is on Chennai Metropolitan Area (CMA), an agglomeration ranked 13th in the ranking of global coastal cities being the most exposed to losses due to flooding in the 2050 time horizon [28], but also already experiencing increasingly severe flooding events due the combined impacts of the changing climate and uncontrolled urbanisation. The devastating floods affecting Chennai in 2015 had put the spotlight on this city as being in dire need for efforts to improve its resilience to the increasing flood risk, which makes this study even more relevant.

The paper explores the potential for reorienting the human-nature interactions through socio-ecological resilience measures in this highly vulnerable urban region in a developing context. What are the barriers and potentials for implementing evolutionary resilience in Chennai at the local, city, and regional scales? In other words, what is the bottom-up community action capacity, and to what extent could it be complemented by cross-scale planning for resilience to the growing flood risk? The paper strives to answer these research questions, emphasising the operational barriers and pointing to opportunities for implementing a resilience strategy for Chennai and its urban region. Building on the literature and policy documents research, field visits, stakeholder interviews, and a community engagement workshop, the paper explores these barriers and potentials across spatial and temporal scales. Beyond bringing novel empirical evidence on Chennai, the paper also innovates by making a conceptual link between evolutionary resilience [29] and the multi-level approach [2], being the core of this study's analytical framework.

The remainder of the paper is organised as follows. The next section outlines the theoretical framework for this study. This is followed by a section presenting the case study and outlining the research methods used. Then, Section 4 presents the empirical results. Finally, the last section discusses the key findings, the implications for planning and policy, as well as the avenues for further investigation.

\section{Theoretical Framework}

The study builds on a combination of insights from two bodies of theory: evolutionary resilience [29] and multi-level approach [2]. Evolutionary resilience is an approach that considers resilience as being beyond a return to normalcy [30]. Resilience is envisioned here as a factor enabling complex socio-ecological systems to continuously change, adapt, learn, and evolve in the face of increasing risk and vulnerability. When applied to the context of urban planning, evolutionary resilience highlights the importance of the link between social and institutional processes and the natural and biophysical processes. This entails addressing different actors, institutions, and spatial and temporal scales.

Evolutionary resilience relates to a relational understanding of space, which is fluid, socially constructed in relations between people, objects and events, and calls for an adaptive perspective on planning, that is, responding to the fluidity and uncertainty of urban processes, being flexible, and seeking to exploit transformative opportunities that this fluidity and uncertainty brings [31,32]. This contrasts with the engineering-based approach to resilience, connecting to absolute (physical) understanding of space, and the blueprint planning approach. The adaptive planning approach that evolutionary resilience calls for requires from the planners' agility, openness to experiments, and creativity, but also it pushes the planners to engage in networks with a range of stakeholders and to put in place participatory processes to include diverse voices, interests, and types of knowledge (including traditional local or tacit knowledge) that the diverse stakeholder groups can bring forward [31,32]. However, for integrating resilience into planning, it is not only critical to ensure active stakeholder engagement in decision making [33], but also to build awareness among the urban stakeholders included in decision making and implementation of resilience policies and strategies to ensure their effectiveness [34].

The evolutionary resilience approach further emphasises the relevance of local values and capacities, as well as changes in societal conditions that impact the interactions between 
human and natural systems. These local values can be recognised by understanding the socio-cultural context $[14,35]$. Hence, focus is laid on the importance of local adaptation strategies that influence human-nature interactions through social changes. What is more, local level actions are the most tangible in terms of influencing resilience. Wilson [12] argues along these lines and in the favour of community resilience and its effectiveness in terms of building resilient human communities. Multiple authors have also highlighted the need for collective action to build local level bottom-up actions $[25,36]$ and the potential of a polycentric governance model to empower local communities to cope with climate risks [36,37]. Finally, Wilson [12] emphasised a crucial link between resilience of socioecological systems with the importance of socio-cultural context, and hence placed focus on community-driven resilience measures. This, he argues, is relevant for all scales, even to the macro scale of a region.

Evolutionary resilience approaches urban planning strategies as a socio-ecological resilience mechanism in which human and nature are interconnected and interdependent [29]. Considering this, in the case of Chennai, the imbalance in this relationship is the root cause to the vulnerability, and therefore attempting to reorient human-nature relationships in the region is the most appropriate, making this approach particularly relevant for this case. Operationalising evolutionary resilience in urban planning essentially entails the design of integrated networks across scales that work together as well as independently and together change, adapt, learn, and evolve.

However, the evolutionary resilience approach was conceived for the local and smallest scale; it is therefore a challenge to apply it to develop strategies that cut across scales, from local to regional and back. This is where a multi-level approach [2] comes into focus. A multi-level approach to socio-technical transitions $[2,38]$ suggests that human societies function on three scales, namely, the macro (landscape), meso (regime), and micro (niche). The macro scale is that of the societal trends such as infrastructure, economy, culture, and politics that drive overall processes. The regime consists of the institutional set up and the link between the macro and micro scale. The Niche consists of local level composed of individuals, groups, organisation, and projects. The local level is key to innovations that can later be upscaled to the macro scale and shape and transform the landscape. When interpreted in the context of urban planning and resilience, the multi-level approach can be conceptualised as macro, integrated planning and visioning; meso, institutions; and micro, local adaptation strategies. Institutions play an important role in the governance of transition by mediating the interests between the micro level actors, and provide a basic framework for the local level innovations to shape the macro level context $[2,38]$. This approach is thus crucial for establishing synergies between the bottom-up strategies and the top-down spatial vision, as illustrated by the successful implementation of the Room for the River programme in the Netherlands, which employed a multi-level governance institutional framework for linking diverse policy objectives across multiple spatial scales into integrated plans and spatial designs for improving resilience to fluvial flooding [39].

The above theoretical framework (see Figure 1) provides a conceptual lens for exploring the barriers and potentials for evolutionary resilience in Chennai. In particular, the distinctions between macro, meso, and micro scales, borrowed from the multi-level approach, are used to investigate (1) the scope for developing an integrated vision for resilience of the Chennai region (macro); (2) the presence and the capacity of institutions to connect the different stakeholders and mediate their interests (meso); and (3) the barriers and potentials developing local adaptation strategies for flood resilience in a bottom-up manner. 
MULTI-LEVEL THEORY

(Zevenbergen et al., 2010)

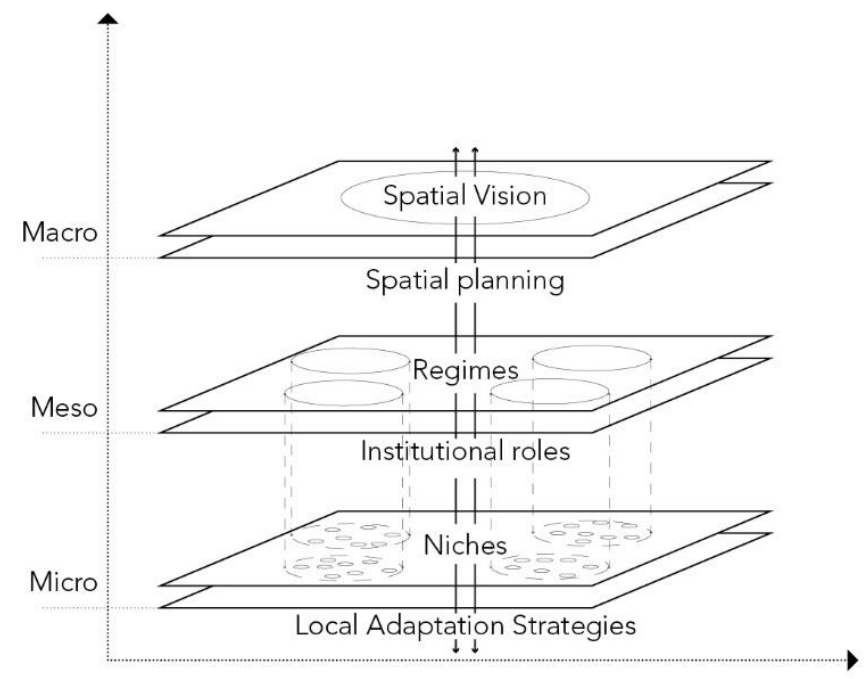

Figure 1. Conceptual framework: operationalising evolutionary resilience using multi-level approach (Source: adapted from [2]).

\section{Methodology}

\subsection{The Case Study}

Being deltaic in nature, the Chennai Metropolitan Area or 'CMA' (see Figure 2), is naturally prone to flooding. While floods have now become an annual occurrence, the response to it and modification of urban practices has not been addressed actively. In fact, the CMA has developed without reflecting on its natural physiography, by obstructing its natural hydrological system due to building over flood plains, marshes, lakes, and ponds [40]. The growth pattern reveals noticeable violations of building over sensitive areas and, in many cases, clashes with the natural hydrology pattern. The vulnerability towards floods has been directly linked to the disruption of the natural drainage system and the encroachments of the catchment areas [41]. At its inception, the city was initially planned with a sophisticated water network, traditionally called the 'Yeri' system, with synergy between the natural water bodies, catchment areas, river systems, marshlands and human-made dams. However, with rapid urbanization and the extension of city limits, this water network was gradually clogged and undermined due to encroachment of riverbank and water sensitive areas by informal settlements, industries, and residential and institutional developments. The primary reason for this unprecedented urbanization was the lack of control of the urban development processes through systematic urban planning [42]. With $90 \%$ of the open swamps taken over by built developments and approximately 150,000 illegal structures over riverbanks and dry channels, the overall region has become increasingly vulnerable to floods with the water-carrying capacity of the natural drainage system severely compromised [43]. Hence, the combination of climate change impacts and human induced vulnerabilities has made the region extremely prone to flooding [44]. The region is ill-equipped and continues to urbanize following these patterns, despite the increasing flood risk, and the recent experiences of severe flooding bring the link between uncontrolled urbanisation and vulnerability to the impacts of the changing climate to light. Moreover, the deprived communities living next to rivers and canals of Chennai are (unsurprisingly) most at risk and the most vulnerable to flooding, however, perhaps paradoxically, the experience of flooding and the hardship that it brought did not trigger learning processes among them, and did not help to improve their capacity to cope with such disasters which are increasingly likely to happen in the future [45]. Hence, there is a conflict between human aspirations and nature's capacity, and a deepening socio-spatial 
injustice which urgently calls for solutions. All this makes Chennai a salient case study and a source of relevant lessons for other rapidly urbanising urban regions in the Global South facing similar tensions between urbanisation, inequality, and vulnerability to flooding.

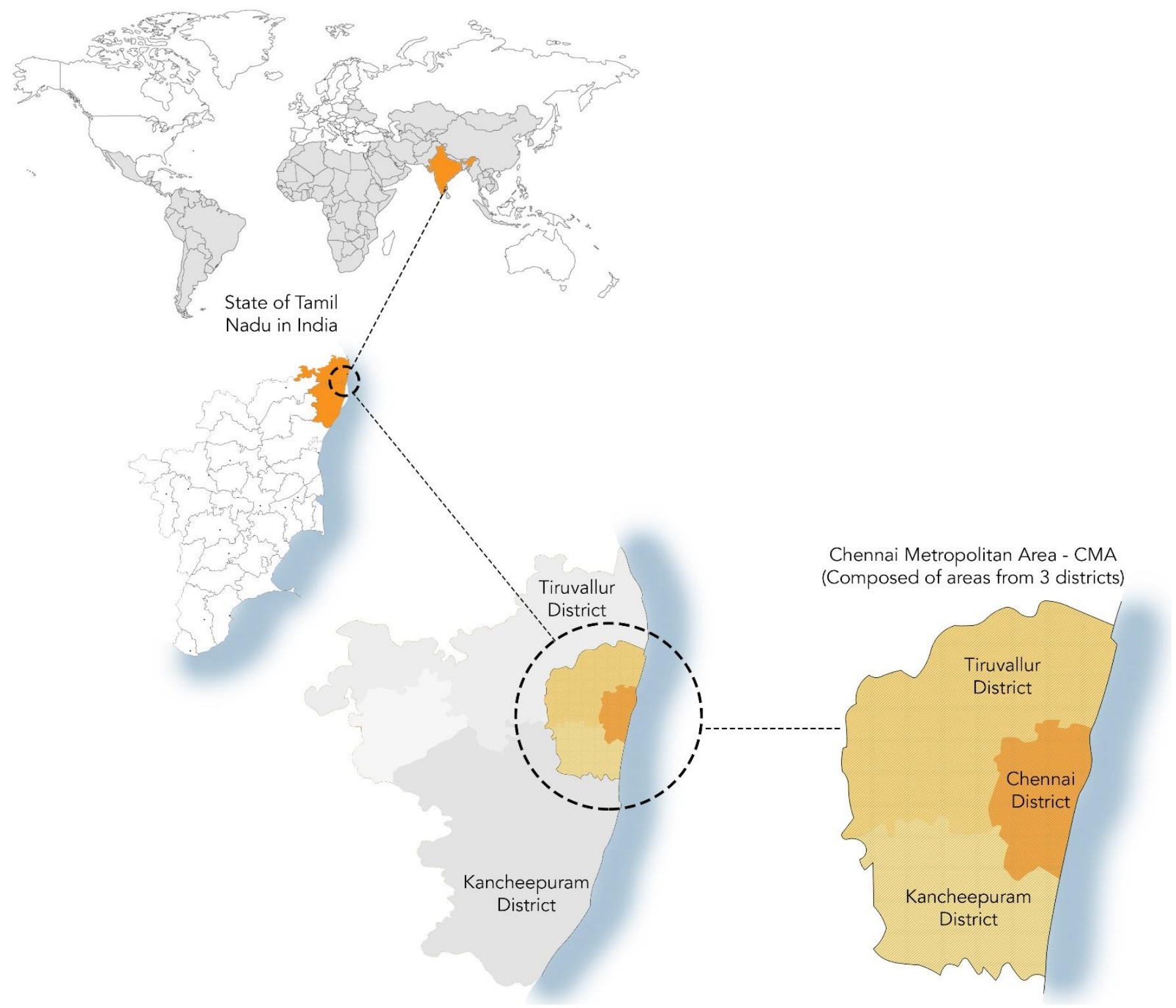

Figure 2. Geographical location of the Chennai Metropolitan Area in India (Source: Authors).

\subsection{Data Sources and Research Methods}

As a basis for the research, a literature review, as well as analysis of a range of secondary sources, from government documents, policy and planning reports, newspaper articles, and historic data and Geographic Information System (GIS) information, were used. The original data was sourced during a field trip to Chennai involving stakeholder interviews, complemented by citizen questionnaires on flood risk, on-site observations, and a stakeholder workshop. This combination of research methods allowed the triangulation of insights, ensuring the robustness of the data and its analysis.

Stakeholder interviews were conducted in a semi-structured manner (see interview guide in Appendix A) to assess involvement of different actors in activities that have a bearing on Chennai's resilience to flooding (spatial planning, water management, institutional arrangements, and ongoing urban programmes, etc.), to explore their strengths and interests in the resilience of Chennai. This diversity of perspectives collected through 
interviews allows us to maintain objectivity in the research. A total of 12 stakeholders were interviewed, consisting of 3 women and 9 men. The interviewees were chosen from various backgrounds and organisations currently involved in the urban development and governance of Chennai, such as urban and regional government tiers, local and global non-governmental organisations based in Chennai, business associations, research institutes, and architecture and urban design practitioners. These individuals were selected based on the positions they occupied in their respective organisations, from mid to senior level, including directors, to ensure that the diversity of age, experience, and influence in the organisation was considered. The interviewees selected were involved or previously involved in initiatives pertaining to the urban development and water management in Chennai, with some having several decades of experience in the city's urban works departments. The interviews were coded in a 'Problem-Potential-Challenge' table to compare and identify the most recurrent views.

An open community co-evaluation workshop was organised in a physical setting in Chennai in February 2018 as part of the fieldwork, in order to co-explore the potentials for building community resilience with the local stakeholders, and to assess local awareness and interest in resilience strategies. The workshop participants were recruited via social media. The format for the workshop was a short presentation of the ongoing research, 60 min of debate and discussion, and finally a 90-min session of co-evaluation of a range of possible resilience solutions. The 'problem tree approach', a knowledge co-creation tool inspired by the methodology developed for the Horizon 2020 project REPAiR [46] (see Appendix (), was used to integrate perception of the problems, its spatial and functional implications, potential solutions, and finally the process of its realisation on the ground. A total of 15 participants (consisting of 11 women and 5 men) attended the workshop (see Figures 3 and 4), including local residents, architecture students, researchers, and practitioners from the sectors of engineering, architecture, urban planning, and NonGovernment Organisations. In addition to the workshop, participants also filled out questionnaires (see Appendix B) focusing on the social and community aspects of resilience and the potential areas of intervention such as the spatial environment, policy, and research.

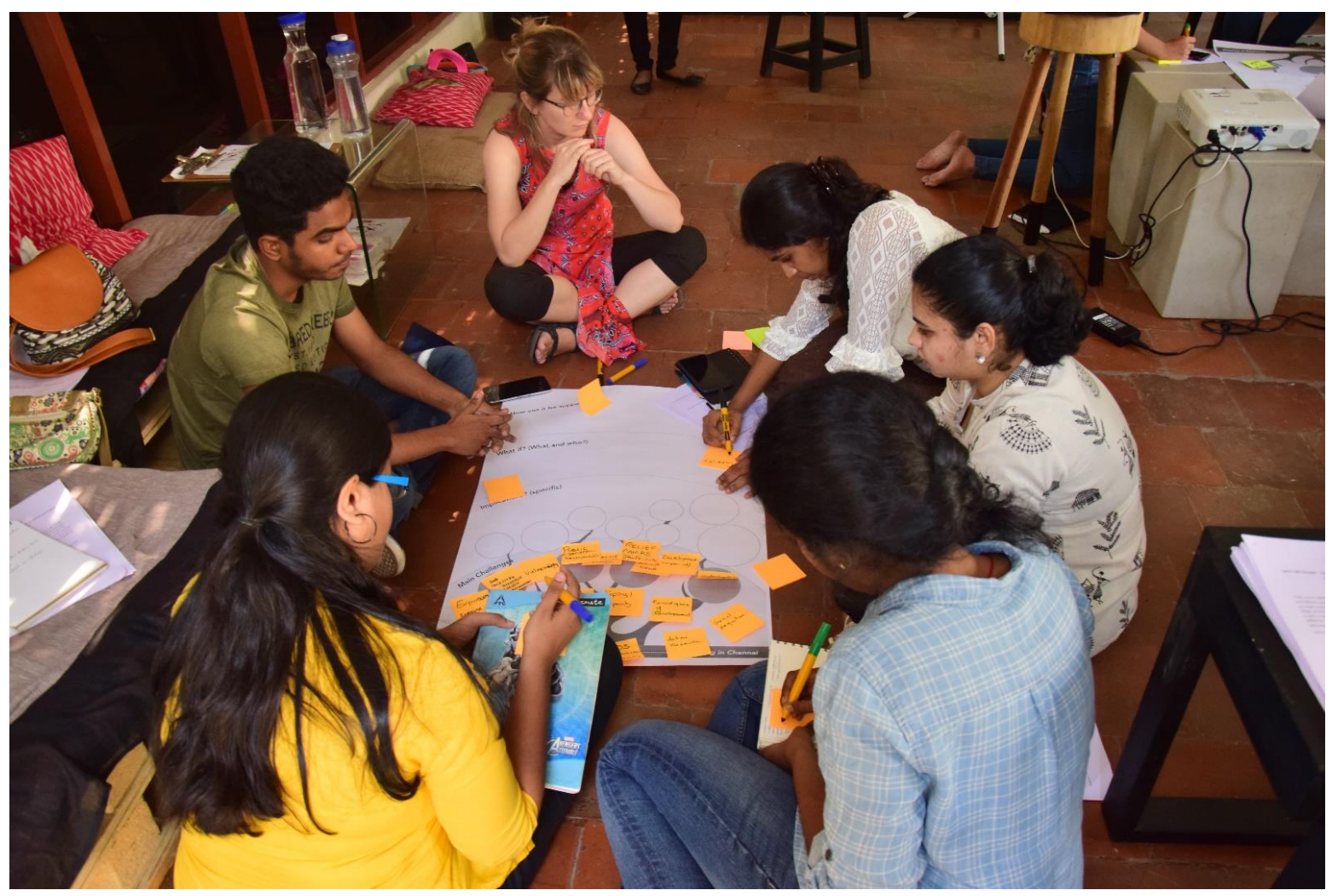

Figure 3. The 'Problem tree approach' used at the community co-evaluation workshop. Source: Authors, building on [46]. 


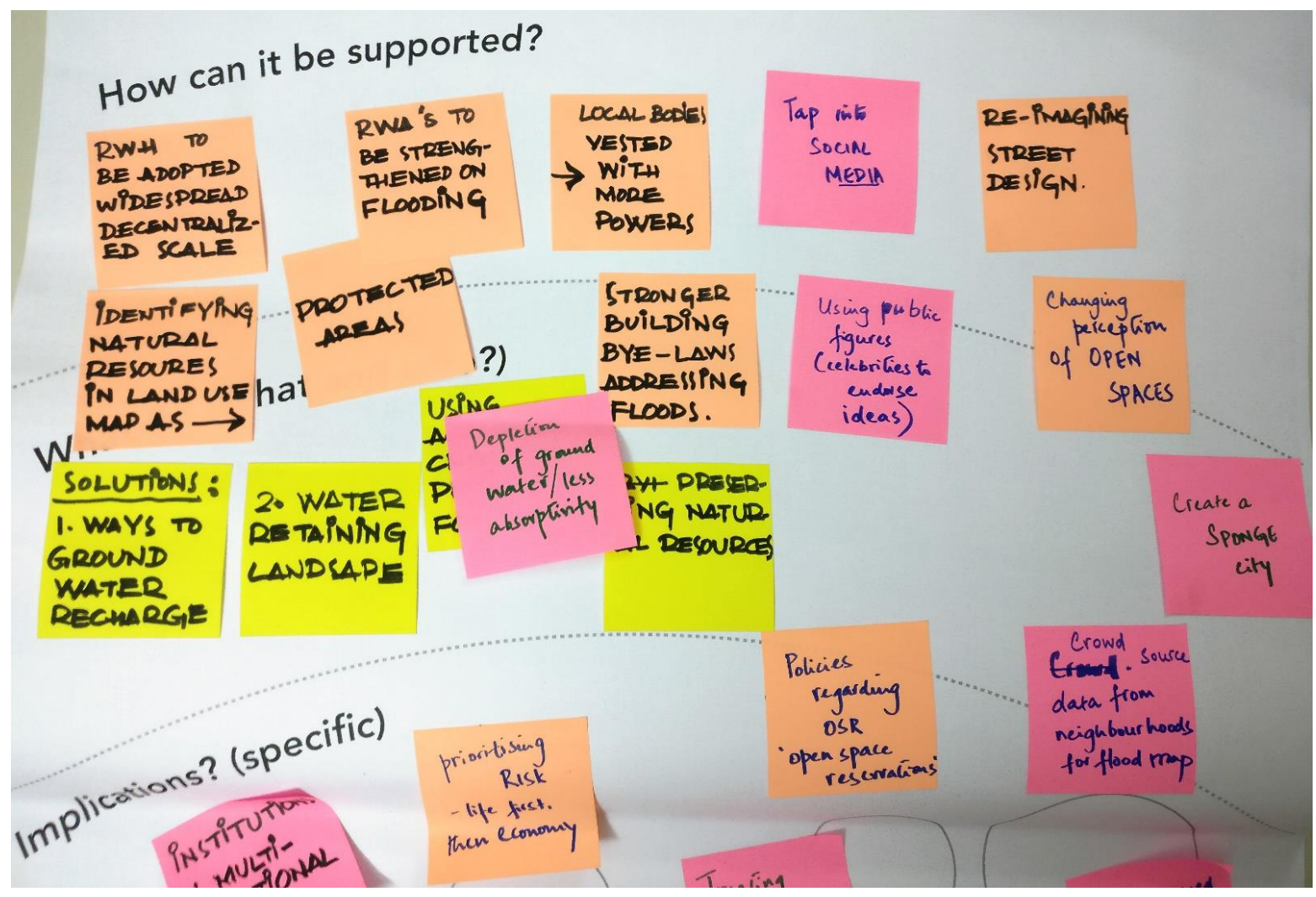

Figure 4. Outputs from the community co-evaluation workshop. Source: Authors.

\section{Exploring the Barriers and Potentials for Socio-Ecological Resilience in Chennai}

The three scales of the multi-level approach, together with the temporal dimensions, are used to structure the exploration and analysis of the barriers and potentials for developing evolutionary resilience in Chennai. For clarity of the argument, for each of those four elements, barriers and opportunities were categorized as (1) socio-cultural, (2) economic, (3) environmental, (4) spatial, (5) technical, or (6) institutional.

\subsection{Micro: Barriers and Potentials for Local Resilience Strategies}

On the micro scale, the main barriers for bottom-up resilience strategies identified were socio-cultural, institutional, spatial, and environmental. During the fieldwork it was observed that the existing waterbodies, waterways, and adjacent public spaces are, in most cases, neglected and in poor condition. In addition to pollution from sewage and solid waste, the edges lining these water bodies are often left untreated and hence come across as leftover wastelands rather than lush water edges (see Figure 5). As the interviews and the stakeholder workshop revealed, this is largely due to the lack of awareness about the values of urban water and risks related to climate change and a crippled ecosystem. This spatial barrier of mismanaged water edges is further aggravated by the socio-cultural barrier of lack of awareness towards the need for it. One interviewee argued that these undefined lands, known as 'poramboke' (roughly translating to no man's land), just through its nomenclature, had suffered a systematic neglect from public perception over the years. In recent years, the word 'poramboke' has attracted the attention of water engineers and the public due to issues of encroachment and mismanagement of these spaces [47]. 


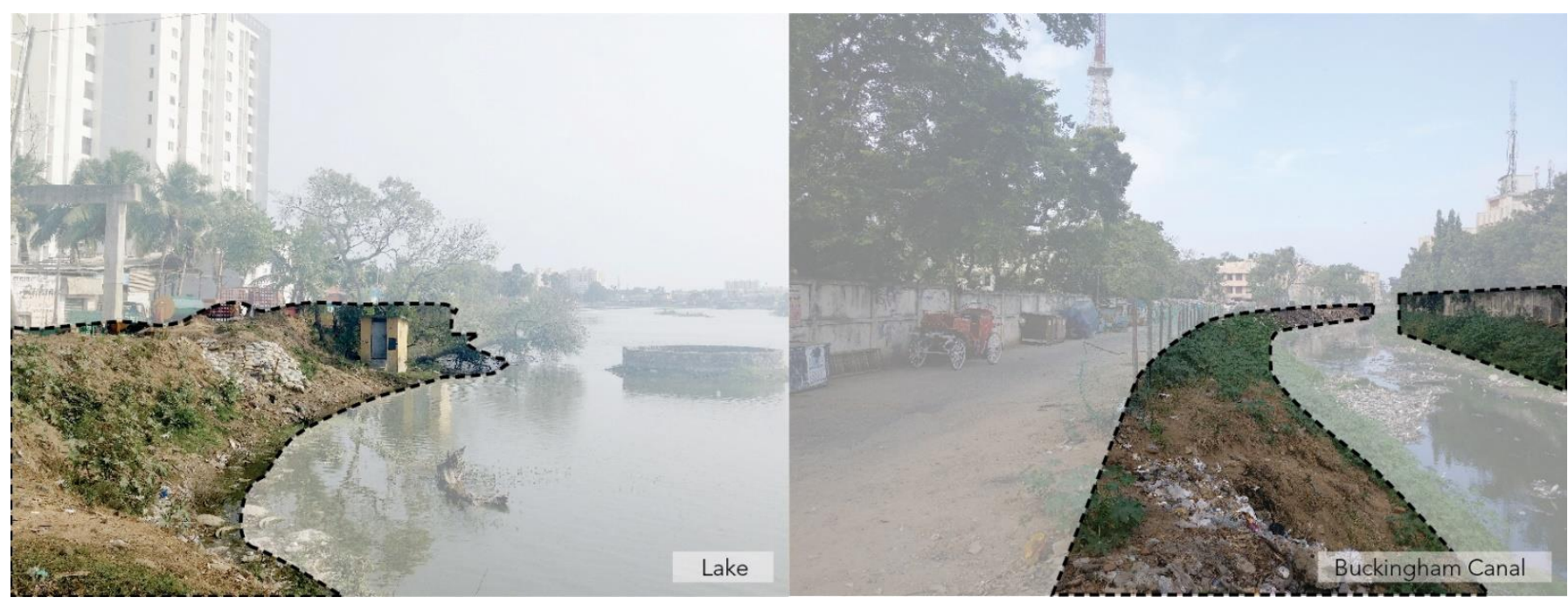

Figure 5. Neglected state of water bodies and surrounding edge areas. Source: Authors.

The lack of awareness of the value of these waterfronts and water bodies could be linked to low civic engagement and participation at the local level, as highlighted frequently by interviewees. There is also low interest among small businessmen and hawkers to identify the risks related to human-nature conflicts. This is surprising, as in December 2015, nearly 150,000 street vendors were directly affected by the floods [48]. According to an interviewee from the Madras Chamber of Commerce, multiple small businesses eventually shut down due to the inability to cope with flood loss, as the road to recovery was often expensive and individualistic. This further emphasizes the need for civic bodies that not only support the values of socio-ecological resilience, but also support these businesses at the time of disasters. As a result of rapid urbanisation over the last two decades, the natural green areas and water bodies that provide buffers and enable the city's water management by absorbing and directing water away from built areas across the city have been threatened. Chennai features amongst the least in green cover at a meagre $15 \%$ [49] in the inner-city areas and even lesser in the less developed suburbs, which is very low as compared to other major metropolitan areas in India $[49,50]$. While urbanisation in Chennai increased from $1.46 \%$ to $18.55 \%$ in the period between 1991 and 2012, vegetation cover fell by $22 \%$, and, if this trend continues, the loss might increase to $36 \%$ by 2026 [51].

As per the regulations in the 1996 Urban Development Plans Formulation and Implementation Guidelines of the Urban Development Ministry, a metropolitan city is required to have $20-25 \%$ of recreational spaces. These recreational spaces are those that are classified as parks, playgrounds, botanical gardens, and open spaces. However, while analysing data of the First Master plan 2006 (Table 1) and the Second Master plan 2026 (Table 2) drafted by the CMDA, open space and recreation in the city is just about $5.68 \%$ in the Second Master plan 2026, which is currently the urban plan used as a guide until 2026. This was the latest land use projections at the time of the research. The Third Master plan is currently under development as of 2021, and hence these land use percentages will be updated. This general lack of priority to open space clearly reflects in the spatial structure of Chennai-each resident has only 0.49 sq.m of open space [52]. This, when connected to the loss of the natural drainage system, brings the need for blue-green infrastructure to focus. In fact, blue-green infrastructures are essential moving spaces for water in urban environments [2], and hence are pivotal for ensuring resilience to flooding. 
Table 1. Existing Land use 2006. Source: CMDA Second Masterplan 2008.

\begin{tabular}{ccccc}
\hline & \multicolumn{3}{c}{ Existing Land Use 2006 } & \multicolumn{2}{c}{ Rest of CMA } \\
\hline & \multicolumn{2}{c}{ Chennai City } & \multicolumn{2}{c}{ Percentage } \\
\cline { 2 - 5 } & Extent in Hectares & Percentage & Extent in Hectares & 21.87 \\
Residential & 9523.18 & 54.25 & $22,876.51$ & 0.37 \\
Commercial & 1244.81 & 7.09 & 390.04 & 6.28 \\
Industrial & 908.42 & 5.17 & 6563.4 & 3.01 \\
Institutional & 3243.39 & 18.48 & 3144.35 & 0.19 \\
Open Space and Recreation & 366.43 & 2.09 & 200.26 & 11.92 \\
Agricultural & 99.29 & 0.57 & $12,469.65$ & 2.33 \\
Non-urban & 82.46 & 0.47 & 2433.3 & 54.03 \\
Others (Vacant, forest, hills, low & 2086.93 & 11.89 & $56,506.6$ & \\
lying, water bodies, etc.) & & & & 54.03 \\
\hline
\end{tabular}

Table 2. Proposed Land use 2026. Source: CMDA Second Masterplan 2008.

\begin{tabular}{|c|c|c|c|c|}
\hline \multicolumn{5}{|c|}{ Proposed Land Use 2026} \\
\hline & \multicolumn{2}{|c|}{ Chennai City } & \multicolumn{2}{|c|}{ Rest of CMA } \\
\hline & Extent in Hectares & Percentage & Extent in Hectares & Percentage \\
\hline Primary residential use zone & 5916.35 & 33.58 & $29,705.21$ & 29.32 \\
\hline Mixed residential use zone & 2426.9 & 13.78 & $12,392.07$ & 12.23 \\
\hline Commercial use zone & 714.24 & 4.05 & 746.08 & 0.74 \\
\hline Institutional use zone & 2868.97 & 16.28 & 3238.5 & 3.2 \\
\hline Industrial use zone & 691.83 & 3.93 & 6678.86 & 6.59 \\
\hline $\begin{array}{l}\text { Special and hazardous industrial } \\
\text { use zone }\end{array}$ & 130.67 & 0.74 & 3355.09 & 3.31 \\
\hline $\begin{array}{c}\text { Open Space and recreational } \\
\text { use zone }\end{array}$ & 1000.65 & 5.68 & 416.45 & 0.41 \\
\hline Non-urban & 133.31 & 0.64 & $11,019.6$ & 10.88 \\
\hline Urbanisable & & & 1882.01 & 1.86 \\
\hline $\begin{array}{l}\text { Others (Vacant, forest, hills, low } \\
\text { lying, water bodies, etc.) }\end{array}$ & 3754.79 & 21.31 & $31,864.54$ & 31.46 \\
\hline Total & $17,617.7$ & 100 & $101,298.42$ & 100 \\
\hline
\end{tabular}

Traditionally, in the Chennai Metropolitan Area, the water infrastructure providing flood mitigation mechanism was that of a hierarchical 'Yeri' network which carried water through a string of channels and waterbodies, eventually draining into the river. Each watershed in this system had its unique set of characteristic features. For example, temples which play an important social and cultural role in the society as places of worship and congregation were initially integrated into the network via temple tanks. A deeper study into this network revealed that, similar to the temple tank, each water body not only served as urban drainage, water storages, and contributed to the local biodiversity, but also was central to the social network, as it provided spaces for culture, recreation, and social behaviour. The loss of this network has hence resulted in the loss of the associated socio-cultural values, and in turn has affected human-nature interactions and awareness of the water system.

The analysis of the interviews, community workshop transcript, and field visit observations revealed four factors contributing to this situation: (1) the mismanaged commons or water edges as the spatial barrier; (2) the lack of civic awareness as the socio-cultural barriers; (3) the deteriorating water network as the environmental barrier; and (4) limited focus of land-use for open space and recreation as an institutional barrier. The following recommendations are made. During the stakeholder interviews, the community co-evaluation workshop and comparative studies of successful community resilience projects, potentials for socio-ecological restoration of the water network in Chennai were explored. An example 
of such initiatives is the community-led restoration of the Chitlapakkam lake in Chennai [53]. As discussed during the workshops, linking environmental revival with cultural revival directly responded to the challenges identified, suggesting that traditional festivals and cultural events could be used to influence, educate, and spread awareness about water. This awareness programme could further be linked to school curriculums. To promote the values of socio-ecological resilience, focus groups, participatory planning measures, and civic engagement strategies could pave the way for an integrated and inclusive community effort. Design proposals which tap into community capacity building, community capital and behavioural change can further impact the perception of the environment and educate the citizens. Spatial interventions that merge public space, the commons, blue-green urban water strategies, and activities and campaigns related to water conservation can also be used as a tool to overcome barriers at the micro scale. The ultimate aim would be to build capacity and knowledge at this micro level, to ensure the citizens not only cope with future risks, but also ensure the resilience of the blue-green networks in the future.

\subsection{Meso: Exploring Governance Capacity}

At the meso level, the barriers identified were mainly economic and institutional. Chennai has always been of economic and political importance since its establishment as a major British port in the colonial era. Economic growth has been at the forefront of the goals of the State of Tamil Nadu since the liberalization of the Indian economy in 1991. Citing an opportunity for industrial development, the then State administration actively promoted policies and regulations that enabled the inflow of Foreign Direct Investment (FDI) into the capital city, Chennai. Hence, by the early 2000s, the ruling government sought to 'Globalise Chennai' and improve and develop its industrial sector by setting up Special Economic Zones (SEZ) and making economic laws in the region lenient to attract more investment from Multinational Companies (MNC). SEZs are essentially geographic areas with economic laws more liberal than the country's domestic economic laws. This led to multiple industrial giants setting up base in Chennai, and it soon became an automobile, industry, and Information Technology/Information Technology Enables Services (IT/ITES) sector haven. The famous IT corridor along the Old Mahabalipuram Road (OMR), which runs parallel to the Buckingham Canal, was only set up in 2005. Known as the 'new Shenzhen', industrial nodes were developed across the region, triggering urban sprawl around these nodes [54]. The Chennai Metropolitan Development Authority (CMDA), set up as part of the Tamil Nadu Town and Country Planning Act in 1971, is currently the statutory body responsible for urban planning in the CMA. Driven by the ambition to become a global city, the CMDA was heavily influenced by the needs of the MNCs and favoured market-driven urbanization. The Master plan drafted by the CMDA in 2006, which is the currently functional one, exhibited land-use and policy planning which favoured fast economic development. However, this resulted in strong pressures on land development, causing a clash with the natural hydrological system of the region. Increase in demand resulted in the encroachment of land adjacent to water bodies, and often in ponds, lakes, swamps, and marshes being dried and built upon [44,55]. A relevant example is that of the IT corridor mentioned earlier: a $2.1 \mathrm{~km}$ long corridor of industries and commercial units to be built in two phases. The initial setup of the corridor near the Pallikaranai wetlands and the setup of large corporate complexes along the corridor led to a severe loss of wetlands and their ecosystem. In this manner, lack of planned expansions has led to the setup of large scale industrial, residential, and commercial developments in flood prone areas. In addition to being zoned in sensitive areas, such as flood banks and low-lying areas, these developments pose additional risks of pollution and further dilapidation of the water resources. These issues essentially illustrate the lack of synergy between urbanization processes and the natural blue-green system of the region. They further highlight the economic barrier which, as a result, prioritizes fast urban development and economic growth over long term resilient thinking. As pointed out by the participants of the community co-evaluation workshop, Chennai authorities tend to be more reactive 
to current market pressures rather than planning for the future, which is precisely the opposite of what is advocated by the evolutionary resilience approach (see [31]).

Furthermore, a fragmented institutional structure and exclusive governance model was identified as a key problem, and as an institutional barrier to operationalizing flood resilience. This institutional barrier was addressed in nearly all stakeholder interviews, especially by those currently working in or with the Government of Tamil Nadu. The analysis of the institutional structure revealed a highly siloed and fractal arrangement of different bodies working within the same domain but in an uncoordinated manner. In addition, stakeholder interviews also pointed to the neglect of the value of the water bodies by the planning authorities being a major barrier to achieving a water resilient city. As one interviewee pointed out, the 'commodification of water bodies' has resulted in valuable water bodies being taken over by real estate developers, hence gradually leading to the loss of the entire water network in the Chennai region.

The gap between the need to protect the natural water system and market-driven urban planning was unanimously cited by interviewees as a major institutional barrier to realising flood resilience at the regional scale. According to officials at the Chennai River Restoration Trust, one such example is the wrongful categorisation of wetlands, which are an essential link in the hierarchical water network, as 'wastelands'. This dates back to the colonial era when the authorities initially identified these as uncultivable, hence wasted land [56]. As a result of this error, wetlands in Chennai and in Tamil Nadu continued to be exploited in the years that followed due to the lack of regulatory frameworks that safeguarded these sensitive ecosystems from the rapid urban development. A striking example of this mismanagement is the case of the Pallikaranai Wetlands (see Figure 6). From 2450 hectares in 1991, the Pallikaranai marsh was reduced to a mere 500 hectares in 2015 , reducing its water carrying capacity by $70 \%$ and increasing flood risk in the surrounding residential areas [57]. The proposed Land-use plan 2026 drafted by the Chennai Metropolitan Development Authority, showing the northern segments of the wetlands zoned for different types of developments, is a further example of deliberate destruction of wetlands undermining the city's resilience.
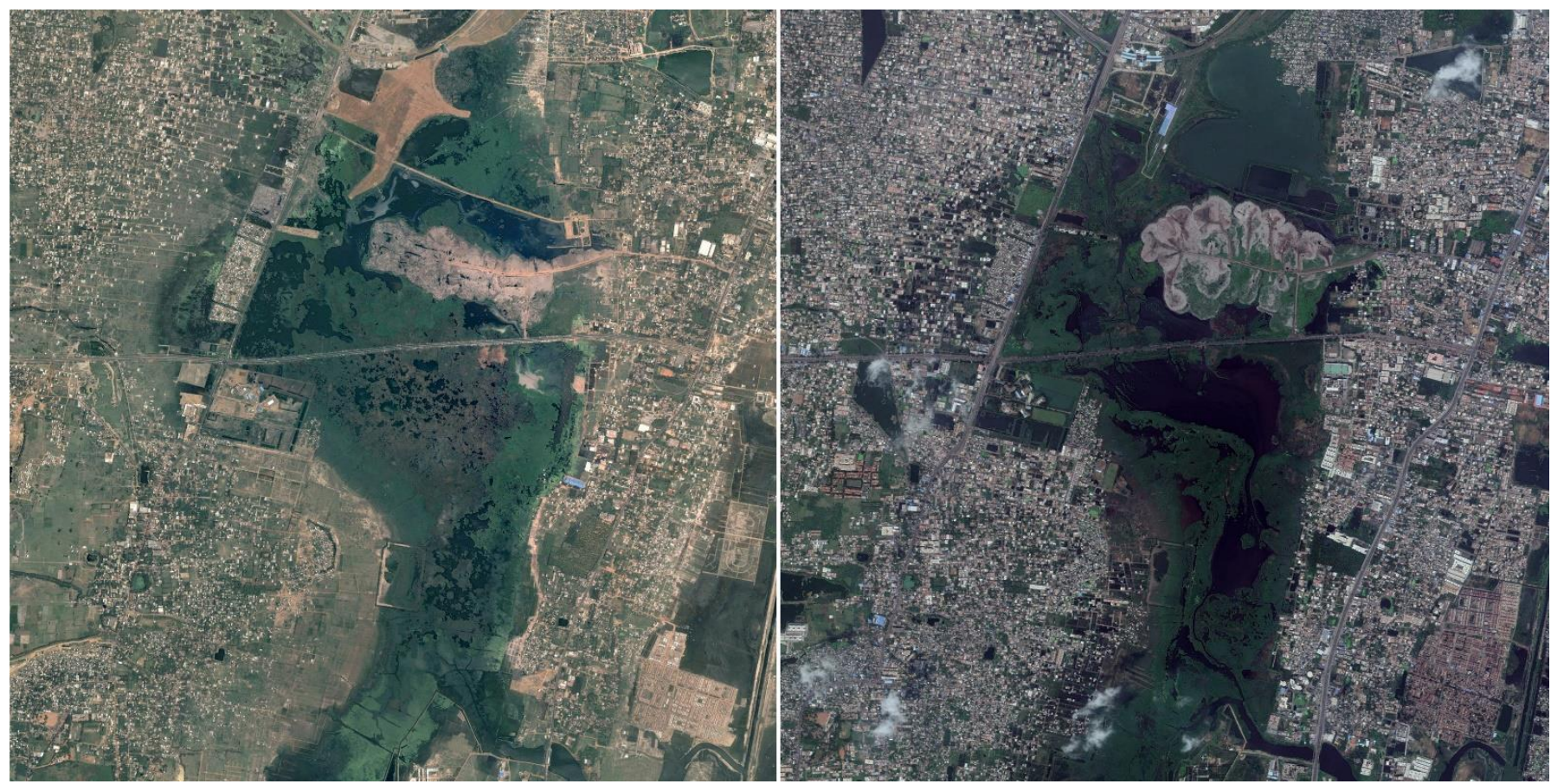

Figure 6. Shrinking of the Pallikaranai Wetlands_Left September 2002, Right September 2016. Source: Google Earth. 
Another institutional barrier identified during the stakeholder interviews is the lack of clarity on who owns waterbodies and who manages it. This is extremely unclear, especially with the fragmented governance structure of the city, hence making it highly difficult for the people to understand who needs to be approached in order to restore a particular water body. Within the array of typologies of water bodies, rivers, canals, and individual water bodies are all owned and operated each by different departments of the government. However, this is not common knowledge. In combination with lack of awareness of water bodies in general, this builds up to a colossal barrier on an institutional as well as socio-cultural level for long-term flood resilience in Chennai.

Institutional reorganisation, strengthening Public-Private partnerships in environmental restoration, dedicated policies, and strict laws and building regulations are amongst the potentials for fostering socio-ecological resilience at the meso scale recognised by interviewees and workshop participants. A further potential identified by the interviewees to enhance resilience was the concept of bottom-up, decentralised management of water bodies, in which people in and around the water bodies would be directly involved in the decision making and water bodies' restoration processes. Additionally, an interviewee also suggested methods of private/corporate companies being involved by 'adopting' a water body and catering to both restoration as well as its subsequent maintenance. Owing to Tamil Nadu's affinity to the Public-Private Partnership model, this integration of the private sector into Chennai's water management could be a worthwhile option in Chennai's water resilient future.

During the community co-evaluation workshops, participants suggested developing a series of building regulations that also tap into existing open spaces through the policy of OSR (Open Space Regulation) which mandates 10\% of site area be used for public purposes. These existing open spaces can be repurposed into micro drainages across the city to manage water more efficiently. Among the potential policy interventions identified was also increased taxation for building in water sensitive and disputed areas, which, however, would require a more far-reaching reform and would be more difficult to implement. Participants also suggested capacity-building on an institutional as well as civic level, through pilot projects and prototypes of designs for water management which could be tested and adopted more widely across Chennai. For instance, the design and testing of an 'ideal' street section that can later be adopted across the city. Discussions in the workshop revealed that, although there are many success stories of individuals practicing successful local water management solutions in their immediate surroundings, for example community-led lake clean ups [58] or community set-up dug wells [59], there lacks one platform that brings together these granulated efforts and promotes similar initiatives. The institution can play an important role in mediating this platform and cataloguing exemplary initiatives into its overall planning framework.

The gaps within the operation and implementation of urban planning could be a result of poor coordination within the institution. According to an ecologist interviewed as part of this research, there is also a "need for a core/expert advisory group comprising urban planners, architects, sociologists, and ecologists". In order to resolve the lack of cross interaction between different departments of the government, an autonomously functioning unit, overseeing urban processes through the lens of flood resilience, was recommended during stakeholder interviews as a first step to close the institutional gap. This unit would have equal representation from the main urban departments in the government, and could bring out efficient coordination and mediation between the goals of the various actors involved.

\subsection{Macro: The Role of Spatial Planning for Resilience of Chennai}

At the macro level, the main barriers were also environmental, institutional, technical, and spatial. First, just as at the micro level (see Section 4.1), the change in land-use of water bodies across the region has resulted in the loss of the region's traditional water harvesting system. This system was one that ensured that water continued to be conveyed to prevent flooding. At the regional scale, this took the form of a hierarchical water network 
working on the principle of one waterbody overflowing into the other through connecting channels, while at the local scale, drainage channels directed water into the nearby water bodies. Owing to the lack of natural slopes and flat topography, a drainage system which was not reliant on gravity for the draining of its landforms was considered the optimum flood defence mechanism [44]. In this topographical condition, canals and channels are extremely important. However, in the case of the Chennai Metropolitan Area, this network has been disrupted at various levels, hence creating an environmental barrier that increases its flood risk.

The lack of a guiding urban vision is evident where, in the absence of strict regulations against building over water bodies, uncontrolled urbanization and encroachments have taken place without reflecting on the natural hydrological system and by building over flood plains, marshes, lakes, and ponds. Over $90 \%$ of open swamps have been taken over by urban developments, reducing the total number of water bodies from 600 in the 1980s to a mere 27 in 2017 as per the National Institute of Disaster Management [40]. While in the 1980s there existed 19 lakes with a surface area of 1130 hectares, the same had been reduced to 645 hectares by the early 2000s [44].

Low-lying areas and flood plains of the rivers are designated as no-build areas according to the planning regulations. In fact, due to their natural vulnerability to inundation, they are also not viable for large constructions for real estate developers. Hence, in many cases, they are the residual spaces in the city. These low-lying areas and flood plains of rivers have been encroached upon by the urban poor. In recent years, several of these informal settlements have been removed, and their inhabitants resettled by the local government. However, in many cases, the resettlement sites are often themselves located in low-lying, flood-prone areas [60]. An example of this is the Perumbakkam housing settlement, which has been built on low-lying marshlands at high risk of flooding. This puts the socio-economically weaker sections at more risk, as they tend to occupy the low-lying areas and the most flood prone zones. This became evident during the field visits where informal settlements were often seen at the edge of the water bodies, in some cases even without a buffer between the water and the built areas. During the field visits, large scale constructions were also identified along the edges of the Adyar river, in this case without sufficient buffer from the river edge (see Figure 7), hence compromising its flood plain. The most interesting observation with respect to encroachment came from the stakeholder interviews in which an interviewee revealed that, during river surveying processes, the walls of concrete structures, regardless of their proximity to the water edge, are marked as the legitimate boundaries of riverbanks, while temporary structures of slums are considered as encroachments. As a result, during river restoration or widening plans, the slums are the worst affected, facing displacement in addition to already being vulnerable to flooding, which further exacerbates their vulnerability.

As a response to floods, the region has currently undertaken storm water drainage systems as its defence measure. These storm water drains are essentially composed of a vast network of concrete, underground drain channels that run along the roadways and work on the principle of gravity, intended for diverting water away from the inhabited areas into the rivers. The fundamental error in this system is that it relies on movement of water from higher to lower points in a topographical context which is flat. Nevertheless, these channels were implemented in the region without taking into consideration the natural contours and slopes of the topography. In a region which is in serious need of a flood defence strategy, this storm water drain network has been implemented to only $30 \%$ of its calculated requirement. Only 7351 drains in the network have been established for $1894 \mathrm{~km}$ of roads, out of a total of $6000 \mathrm{~km}$, so only $34 \%$ of the requirement has been met [61]. All stakeholders interviewed questioned the efficiency of stormwater drains, and further flagged up the lack of maintenance of the system. In fact, they further highlighted that there was no overarching stormwater drainage plan for the entire city and, hence, the implementation of the drain network was often fragmented. This was a key technical barrier that was identified. Parkinson and Mark [62] suggest possible errors in storm water 
drain systems, and how they may often aggravate flooding than mitigate it. In many cases, important drainage outlets are clogged up with pollution or barriers. In addition to this, the southern parts in general are more prone as the flat topography of these areas, combined with higher run-ups, facilitates inundation for longer distances and durations [62]. The combination of a failed storm water drains system and a flat topography led to persistence of inundation for several days at a stretch. This was evident during the floods of December 2015 in Chennai.

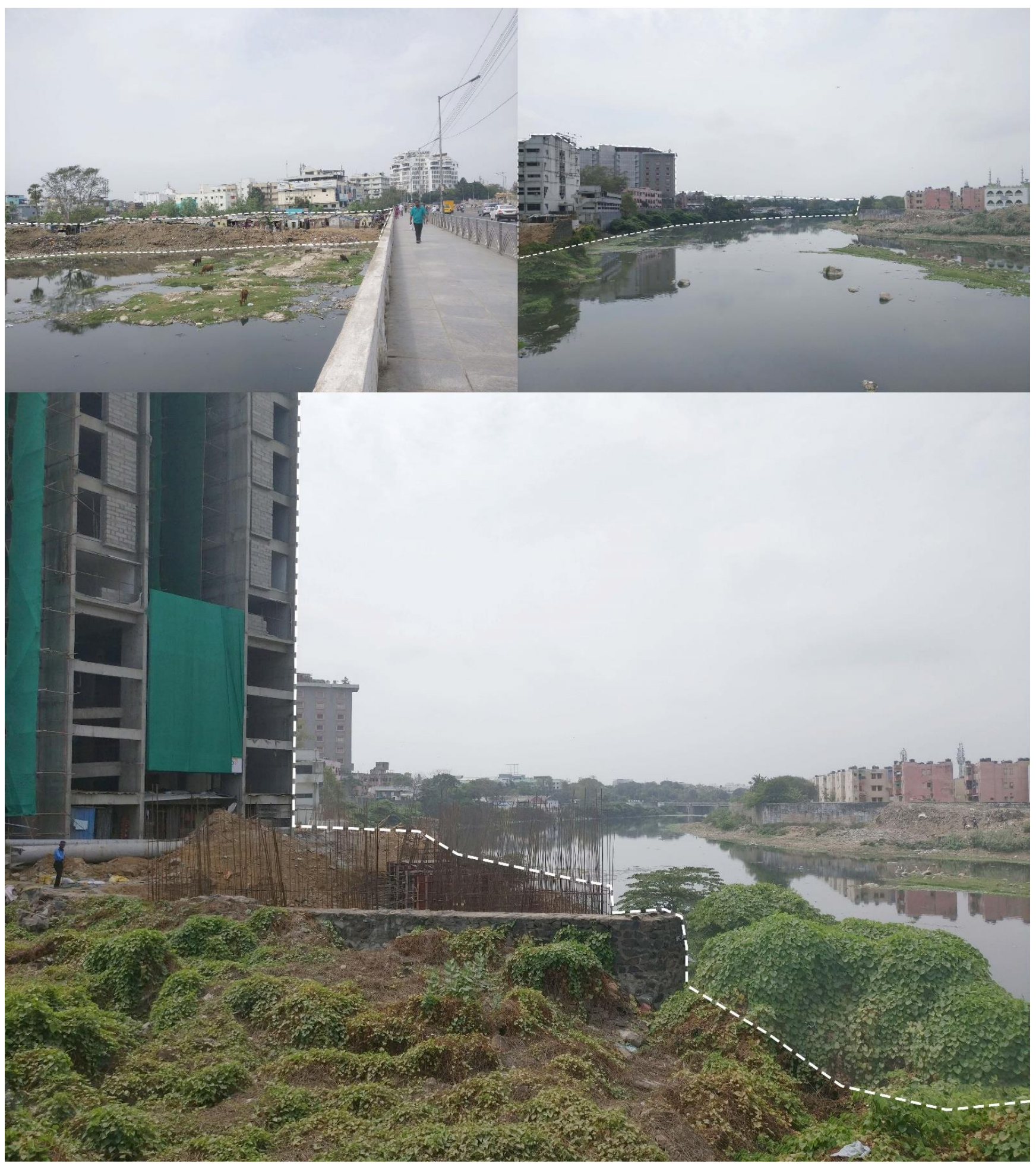

Figure 7. Different types of encroachments along the Adyar River. Source: Authors. 
Since the formation of the CMDA (Chennai Metropolitan Development Authority), the planning authority has drafted Master plans. These plans categorize land-parcels across the region with land-use regulations. However, the region does not have a long-term strategy that governs development processes and growth patterns. The primary influence over urban growth has been transport infrastructure and industrial development. This has resulted in mega-projects that deliver services, for instance, desalination plants, rather than a collective vision to shape the overall region. Hence, short term goals of the city remain localized due to the lack of a guiding vision to safeguard the environment and prepare for climate change over time. In fact, the Greater Chennai Corporation (GCC) has, in the light of recent events, begun to focus on disaster management by identifying vulnerable areas that will be evacuated/safeguarded during floods. Although this is a relevant strategy, the disaster management plan again remains a short-term contingency plan. The main conflict in this matter is that, without a long-term plan, the development already taken place and planned for the future is in jeopardy unless both planners and industrial actors become aware of a plan which safeguards long term urban growth as well as environmental threats.

The above findings point to an urgent need for a regional level strategy for flood adaptation. While long term plans can and should be drawn, it is also important to draft support policies and incentives which can operationalise and uphold the vision on a ground level. Hence, the regional strategy should also include measures to build awareness, as well as to trigger, expand, and sustain stakeholder involvement and interest in the strategy at different scales to ensure a resilient governance model. This was highlighted throughout the research, in the community co-evaluation workshops and especially the stakeholder interviews by the actors who routinely engage with the urban processes in the Chennai Metropolitan Area. The discussions pointed towards a need for an overarching and integrated urban vision steering water management on a local scale, balancing between the top-down and bottom-up approaches. This would allow for operationalising socioecological resilience on a micro level through a regulatory framework provided by the institution at the meso level through policies and governance measures, along with an urban vision providing a tangible spatial framework to direct economic growth and other urban aspirations, while maintaining the environmental values. See summary of the findings across all scales in Table 3.

Table 3. Summary of the key findings on barriers and potentials for resilience strategies in Chennai.

\begin{tabular}{|c|c|c|}
\hline Dimension & Barriers for Resilience Strategies & Potentials for Resilience Strategies \\
\hline Micro (local strategies) & $\begin{array}{l}\text { - Institutional: Limited focus of land-use for } \\
\text { open space and recreation; } \\
\text { Socio-cultural: Lack of civic awareness of } \\
\text { values of water bodies; } \\
\text { limited participation; } \\
\text { - Spatial: Mismanaged water edges; } \\
\text { Environmental: Deteriorating } \\
\text { water network. }\end{array}$ & $\begin{array}{l}\text { - } \quad \text { Linking environmental revival with } \\
\text { - } \quad \text { Awarareness programmes; } \\
\text { - } \quad \text { Focus Groups and participatory processes; } \\
\text { - } \quad \text { Capacity building through } \\
\text { education programmes; } \\
\text { - } \quad \text { Tapping into behavioural changes; } \\
\text { - } \quad \text { inblic spaces and commons redesigned to } \\
\text { integrate blue-green values. }\end{array}$ \\
\hline Meso (institutions) & $\begin{array}{l}\text { Economic: Fast urban growth prioritised } \\
\text { over hydrological values; } \\
\text { Institutional: Fragmented institutional } \\
\text { structure; gaps between urban planning } \\
\text { and safeguarding of environmentally } \\
\text { sensitive areas; lack of clarity on ownership } \\
\text { of waterbodies. }\end{array}$ & $\begin{array}{l}\text { - } \quad \text { Decentralised water management; } \\
\text { - } \quad \text { wablic-Private partnerships in the } \\
\text { - } \quad \text { Exploring building regulations; } \\
\text { - } \quad \text { Capacity building through pilot projects; } \\
\text { - Creating a dedicated body with } \\
\text { cross-cutting representation to } \\
\text { enhance coordination; } \\
\text { - Involving core expert groups. }\end{array}$ \\
\hline
\end{tabular}


Table 3. Cont.

\begin{tabular}{|c|c|c|}
\hline Dimension & Barriers for Resilience Strategies & Potentials for Resilience Strategies \\
\hline Macro (vision) & $\begin{array}{l}\text { Environmental: Ruptured water network in a } \\
\text { flat topography; } \\
\text { - Institutional: Lack of overarching } \\
\text { urban vision; } \\
\text { - Spatial: Encroachments and the lack of check } \\
\text { on an urban scale; } \\
\text { Technical: Poor stormwater } \\
\text { drainage network. }\end{array}$ & $\begin{array}{l}\text { - Overarching urban vision to steer } \\
\text { local development; } \\
\text { - } \quad \text { Policies and incentives; } \\
\text { Balance between top-down and } \\
\text { bottom-up approaches; } \\
\text { - Regulatory frameworks to guide urban } \\
\text { development. }\end{array}$ \\
\hline
\end{tabular}

Source: Authors.

\section{Conclusions}

The paper explored the operational aspects of socio-ecological resilience in the case of Chennai by shedding more light on the barriers for resilience and indicating where there is potential to trigger change. This has been achieved by using an analytical framework based on the multi-level approach [2] and evolutionary resilience [29] and building on insights from fieldwork in Chennai which included site visits, stakeholder interviews, questionnaire responses, and a community co-evaluation workshop.

At the micro scale, the institutional barrier identified was the limited focus of land-use planning on open space and recreation, hence directly impacting blue-green aspects in the city, and the socio-cultural barriers were identified as the lack of civic awareness and limited participation. This was derived through the analysis of existing planning documents, reports, and stakeholder interviews. The spatial barriers were identified as the mismanaged water edges and commons through field visits and interviews with stakeholders involved in the urban development processes in Chennai. Finally, the environmental barrier was identified as the deteriorating water network impacting the ecosystem services delivered through it. This was a result of the analysis of the historical context, and was further corroborated by stakeholder interviews with local ecology experts. To address these barriers to environmental and cultural revival, traditional networks with potential to be tapped into to build community capital were identified as potential solutions. Other potentials, such as awareness programmes, focus groups, and participatory processes to improve civic engagement and connectedness with the local water system were also identified. Moreover, capacity-building could be further addressed through education programmes. As a spatial strategy, public spaces, water edges, and the commons could be redesigned to rehabilitate the city's blue-green network. Overall, in the long term, behavioural change appears essential to achieve socio-ecological relationships that will eventually drive local resilience [63].

On the meso scale, which was understood as the mediator between the micro local and macro regional, the analysis focussed primarily on the institutional structure and efficiency in the CMA. A fragmented institutional structure, coupled with a planning authority influenced by large scale infrastructure and economic development was understood as the major barrier to bringing about flood resilience on a local and regional scale. This silo-ed institutional structure was unanimously expressed across stakeholder interviews with the experts from local government and residents interacting with the institution on a regular basis. To close this gap, as proposed by the stakeholders interviewed and participation in the community workshop, institutional reorganisation with a proposed autonomous body specialising in flood management planning and with equal representation from all urban departments can be recommended. Further to these, cooperation between Public and Private sectors by diverting "Corporate Social Responsibility" funds towards restoration of the spatial environment was identified as a potential by the stakeholders interviewed. It is important to note that political goodwill is also a critical factor, and hence is crucial to implement citywide transformation. Successful policies from abroad, including a robust multi-level governance framework and strong coordinating body, such as the 
Delta Programme in the Netherlands, could also provide inspiration for such a governance set up.

At the macro level, the lack of an overarching urban vision that guides the development of Chennai's urban region was identified as an institutional barrier. Limited public participation in urban planning, and lack of effective feedback mechanisms further exacerbated the gap between policies and requirements on the ground. This was corroborated by all interviewees who identified this to be caused by a lack of integration between the actual urban systems and process, on the one hand, and the governance bodies unable to steer them, on the other hand. The ruptured water network was identified as an environmental barrier, encroachments of the water bodies and edges were identified as spatial barriers and an inefficient stormwater drainage system that aggravates the vulnerability of flooding was identified as a key technical barrier. This observation was born out of field visits along Chennai's waterways, as well as stakeholder interviews with ecology experts in Chennai. Hence, at the macro scale, developing an urban vision to steer local development and regulatory frameworks that enable this vision to be implemented are the main potentials identified.

One of the key lessons from this investigation is the need for a balanced approach between top-down and bottom-up for the case of Chennai. There is a need for a spatial vision on the macro scale to guide urban development, and increased awareness and interaction between socio and ecological settings at the micro scale. The meso scale provides an enabling environment and regulatory frameworks which make these human nature interactions sustainable while keeping the economic and developmental aspirations for the urban area intact. In the case of socio-ecological resilience, the paper hence reveals that the meso level, which relates to institutions and its efficiency, are essential for driving the societal transition in Chennai in the face of climate-related risks.

By identifying barriers and potentials at all these levels, this paper lays out the first steps to planning for socio-ecological resilience in Chennai and operationalises evolutionary resilience. The analysis of the barriers on the grounds of socio-cultural, spatial, environmental, institutional, and economic aspects, offers a useful basis for planning and water management practitioners in Chennai to change the status quo. The potentials explored in this research provide pointers to solutions that can be further built upon.

The concept of socio-ecological resilience is extremely relevant for the Global South, which is increasingly facing climate risk while expanding at rapid rates. The case of Chennai can also be a source of important lessons for practitioners dealing with resilience in this context. First of those lessons is that the role of the institution is essential to maintain balance between the natural capacity and human activity at the macro and micro levels to avoid a conflict in functionality between the two. Second, designing for human-nature interactions is needed to build strong socio-ecological relationships that will eventually drive the resilience process. Third, in complex urban settings, the intertwined nature of the barriers calls for integrated solutions.

Further research could consider the temporal dimensions of the proposed potentials and provide a framework for building evolutionary resilience through short term, midterm, and long-term strategies in Chennai. Moreover, the framework proposed here could be applied in comparative case study research to allow the drawing of more generalisable findings on operationalisation of evolutionary resilience in the cities of the Global South.

Author Contributions: Conceptualisation, N.T. and M.D.; methodology, N.T. and M.D.; formal analysis, N.T.; investigation, N.T.; resources, N.T.; data curation, N.T.; writing-original draft preparation, N.T.; writing-review and editing, M.D.; visualisation, N.T.; supervision, M.D.; project administration, M.D.; funding acquisition, N.T. Both authors have read and agreed to the published version of the manuscript.

Funding: This research received no external funding.

Institutional Review Board Statement: Not applicable.

Informed Consent Statement: Not applicable. 
Data Availability Statement: Spatial and policy data as well as workshop and survey data are available upon request, however, interview transcripts are kept confidential to maintain anonymity of the interviewees.

Acknowledgments: We would like to thank the participants of the workshop in Chennai, the interviewees, as well as the Deutsche Gesellschaft für Internationale Zusammenarbeit (GIZ) GmbH for facilitating the fieldwork.

Conflicts of Interest: The authors declare no conflict of interest.

\section{Appendix A}

1. BACKGROUND:

1.1 What is your role and responsibility in the city's urban development?

1.2 What kind of work do you do?

1.3 What are the goals of your organisation/company?

1.4 What are the tools and methodologies used by your organisation?

2. THE PROBLEM:

2.1 How would you describe Chennai's flood risk and contributing factors?

2.2 What is the problem you are approaching? What do you think is the risk?

2.3 With the people/companies you work with, what is the perception of risk?

2.4 Do you consider climate change as a problem? How do you communicate this to end users?

2.5 What measures are you taking to approach this problem? Awareness building and design?

2.6 Are you aware of the existing flood defence mechanisms in place for Chennai?

3. 2015 FLOODS EXPERIENCE:

3.1 Were you active during the floods?

3.2 What were the city's biggest assets or strong points during the floods?

3.3 Do you think the roads and rail infrastructure was sufficient?

3.4 Need of the hour in terms of spatial terms?

3.5 What do you perceive as safe zones at the time of floods?

3.6 In 2015, what do you think could have been done to prevent the massive flash floods?

4. CURRENT URBAN APPROACH:

4.1 What is your approach to sustainable urban development?

4.2 What are the existing and proposed projects or initiatives?

4.3 How has economic liberalisation 1991 changed the way demand versus supply with respect to floods?

4.4 Does it clash it with the existing land-use plans or goals of the CMDA and its masterplan?

4.5 In addition to the Masterplan 2026 and other development control rules, what infrastructural support do you think Chennai needs?

4.6 In what way do different government schemes support your organisation's efforts?

4.7 Are corporate companies willing to invest in the city's urban development?

4.8 What are the challenges you have faced with respect to governmental and non-governmental factors?

4.9 Are you dealing with socio-economically weaker sections? If yes, how?

4.10 What are the opportunities that you have looked at for improving the current situation?

4.11 Are there any inspirations to what you envision Chennai Rivers as?

4.12 Are you looking at other economic and social opportunities through the project?

4.13 How are you considering biodiversity conservation?

4.14 What is unique about Chennai and what it has to offer? 


\section{STAKEHOLDER COLLABORATION:}

5.1 What are the groups and users you work with? Can you list all organisations and individuals you collaborate with?

5.2 What are the potentials of different groups in Chennai?

5.3 In what ways are you considering diverse stakeholders in your initiatives?

6. INCLUSIVENESS:

6.1 How do you involve the public?

6.2 In what ways are you accommodative to public participation?

6.3 How do you communicate with the users?

6.4 Do you think there is a potential for community engagement, if yes, how?

7. RESILIENCE:

7.1 What does resilience mean for Chennai?

7.2 What do you perceive resilience as?

7.3 What is the key to achieving resilience in Chennai?

\section{Appendix B. Social Resilience and Flooding in Chennai}

1. Name (optional)

2. Background: Age: Gender: Profession: Income range: Lower/Middle/Higher/ Upper class

3. Where do you live in Chennai?

4. Name one water body in your locality and one that you frequently visit in Chennai.

5. Describe the condition of this water body. Explain In terms of seasonal/perennial nature, water level, pollution level, type of pollution (industrial, waste, household), and type of communities contributing to it.

6. Did your locality flood during the December 2015 floods? How deep do you think the inundation (water level) was?

7. Do you live in a naturally flood prone zone? (Floodplains of rivers or water bodies, low lying areas)

8. One unique memory of the 2015 floods?

9. How did you access resources and services during floods? (Ration, healthcare)

10. Assuming that you live in a naturally flood prone zone, where would you consider 'safe' and why? Describe this 'safe place' in terms of type of usage (eg.Civic or public), typology of usage (eg. Residential, Worship, Recreation, Commercial etc), proximity to roadways, resource availability, security (from natural or human threats), and other possible factors.

11. Given the circumstances that you need to leave your locality, where would you seek shelter and help? Why? Describe in terms of distances you can commute, personal relationships, access to resources, affordability, space available per person, living conditions, availability of sanitation, food and water availability). Community infrastructure in Chennai:

12. On a scale of 1 to 10,10 being highest, how would you rate the 'feeling of community' in Chennai? (Samooga Unarou)

13. What do you consider a 'public' place? (Podhu idam)

14. In your neighbourhood, what would you name as the most 'public' place? Why?

15. Please tick those that you think are public?

$\begin{array}{ll}\circ & \text { Apartment block } \\ \circ & \text { Apartment society/complex } \\ \circ & \text { Community centre } \\ \circ & \text { Cultural halls } \\ \circ & \text { Sports grounds/Playgrounds } \\ \circ & \text { Parks } \\ \circ & \text { Schools } \\ \circ & \text { Colleges }\end{array}$




\section{- $\quad$ Places of Worship \\ - Marketplaces \\ - Government buildings \\ - $\quad$ Parking buildings}

16. On a scale of 1 to 10,10 being highest, how would you rate your 'awareness' about the urban issues and proceedings in Chennai?

17. Chennai is among the ' 100 Resilient Cities' pioneered by the Rockefeller Foundation. What do you think makes Chennai Resilient?

18. How do you contribute to make Chennai better?

19. In what ways do you participate in the processes of Chennai?

20. What would you say is the driving factor to participation in Chennai? In contrast, what would you say is the biggest obstacle to public participation in Chennai?

\section{Appendix C}

$$
\text { How can it be supported? }
$$
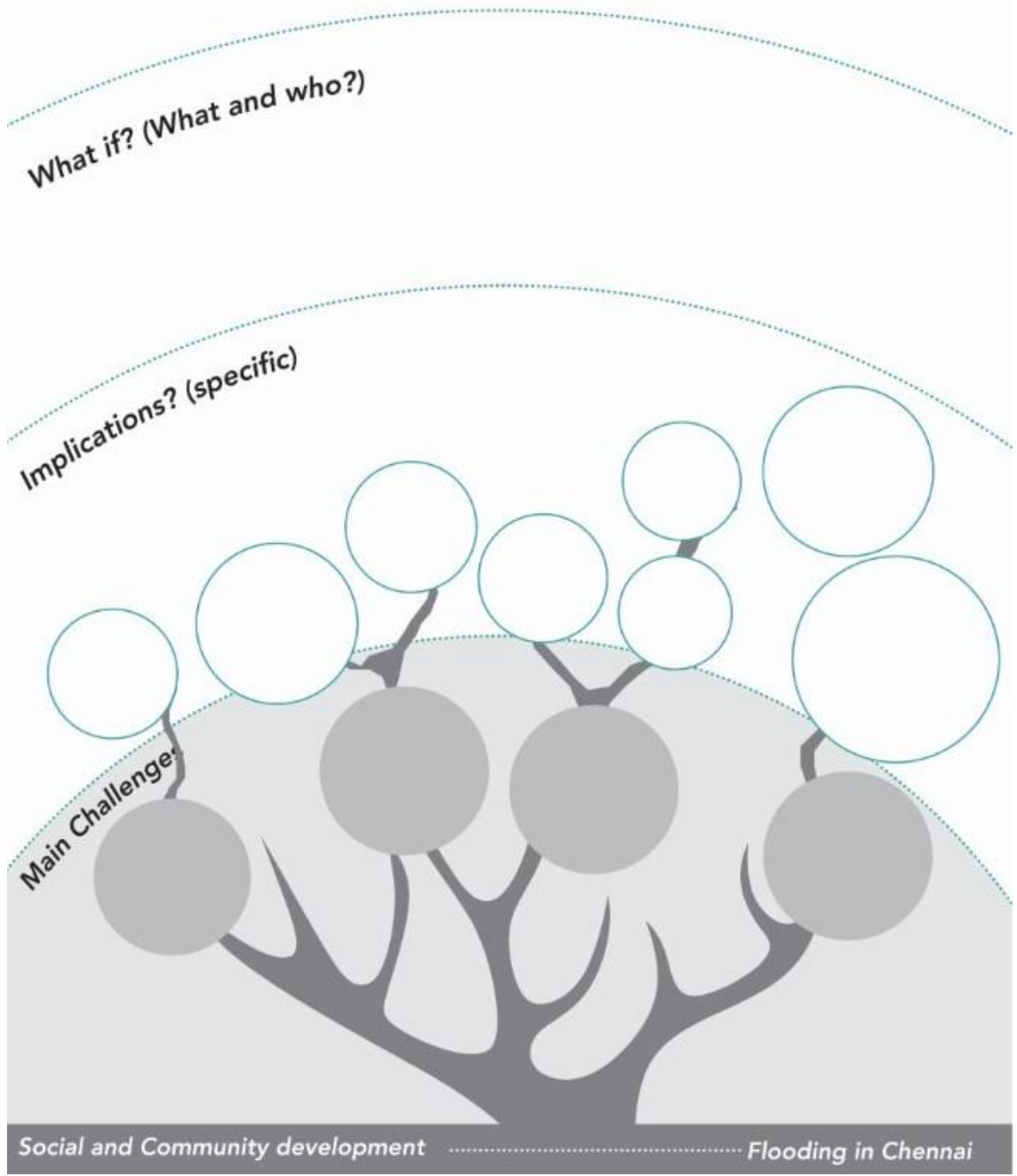

Figure A1. Workshop sheet format using the Problem Tree Approach. Authors, building on [50]. 


\section{References}

1. World Bank. Cities and Climate Change: An Urgent Agenda. Available online: https://openknowledge.worldbank.org/handle/ 10986/17381 (accessed on 16 September 2021).

2. Zevenbergen, C.; Cashman, A.; Evelpidou, N.; Pasche, E.; Garvin, S.; Ashley, R. Urban Flood Management; CRC Press: Boca Raton, FL, USA, 2010.

3. Bulkeley, H.A.; Broto, V.C.; Edwards, G.A. An Urban Politics of Climate Change: Experimentation and the Governing of Socio-Technical Transitions; Routledge: London, UK, 2014.

4. Bulkeley, H.; Castán Broto, V. Government by experiment? Global cities and the governing of climate change. Trans. Inst. Br. Geogr. 2013, 38, 361-375. [CrossRef]

5. Coaffee, J.; Therrien, M.-C.; Chelleri, L.; Henstra, D.; Aldrich, D.P.; Mitchell, C.L.; Tsenkova, S.; Rigaud, É. Urban resilience implementation: A policy challenge and research agenda for the 21st century. J. Contingencies Crisis Manag. 2018, 26, 403-410. [CrossRef]

6. Lu, P.; Stead, D. Understanding the notion of resilience in spatial planning: A case study of Rotterdam, The Netherlands. Cities 2013, 35, 200-212. [CrossRef]

7. Chu, E.; Anguelovski, I.; Roberts, D. Climate adaptation as strategic urbanism: Assessing opportunities and uncertainties for equity and inclusive development in cities. Cities 2017, 60, 378-387. [CrossRef]

8. Dabrowski, M. Boundary spanning for governance of climate change adaptation in cities: Insights from a Dutch urban region. Environ. Plan. C Politics Space 2018, 36, 837-855. [CrossRef]

9. Francesch-Huidobro, M.; Dabrowski, M.; Tai, Y.; Chan, F.; Stead, D. Governance challenges of flood-prone delta cities: Integrating flood risk management and climate change in spatial planning. Prog. Plan. 2017, 114, 1-27. [CrossRef]

10. Hartmann, T.; Driessen, P. The flood risk management plan: Towards spatial water governance. J. Flood Risk Manag. 2017, 10, 145-154. [CrossRef]

11. Ran, J.; Nedovic-Budic, Z. Integrating spatial planning and flood risk management: A new conceptual framework for the spatially integrated policy infrastructure. Comput. Environ. Urban Syst. 2016, 57, 68-79. [CrossRef]

12. Wilson, G. Community Resilience and Environmental Transitions; Routledge: Oxfordshire, UK, 2012.

13. Bush, J.; Doyon, A. Building urban resilience with nature-based solutions: How can urban planning contribute? Cities 2019, 95, 102483. [CrossRef]

14. White, I.; O'Hare, P. From rhetoric to reality: Which resilience, why resilience, and whose resilience in spatial planning? Environ. Plan. C Gov. Policy 2014, 32, 934-950. [CrossRef]

15. McDonough, K.; Hutchinson, S.; Moore, T.; Hutchinson, J.S. Analysis of publication trends in ecosystem services research. Ecosyst. Serv. 2017, 25, 82-88. [CrossRef]

16. Jax, K.; Calestani, M.; Chan, K.M.A.; Eser, U.; Keune, H.; Muraca, B.; O’Brien, L.; Potthast, T.; Voget-Kleschin, L.; Wittmer, H. Caring for nature matters: A relational approach for understanding nature's contributions to human well-being. Curr. Opin. Environ. Sustain. 2018, 35, 22-29. [CrossRef]

17. Therrien, M.C.; Usher, S.; Matyas, D. Enabling strategies and impeding factors to urban resilience implementation: A scoping review. J. Contingencies Crisis Manag. 2020, 28, 83-102. [CrossRef]

18. Torabi, E.; Dedekorkut-Howes, A.; Howes, M. Adapting or maladapting: Building resilience to climate-related disasters in coastal cities. Cities 2018, 72, 295-309. [CrossRef]

19. Béné, C.; Mehta, L.; McGranahan, G.; Cannon, T.; Gupte, J.; Tanner, T. Resilience as a policy narrative: Potentials and limits in the context of urban planning. Clim. Dev. 2008, 10, 116-133. [CrossRef]

20. Anguelovski, I.; Shi, L.; Chu, E.; Gallagher, D.; Goh, K.; Lamb, Z.; Reeve, K.; Teicher, H. Equity Impacts of Urban Land Use Planning for Climate Adaptation: Critical Perspectives from the Global North and South. J. Plan. Educ. Res. 2016, 36, 333-348. [CrossRef]

21. Vale, L.J. The politics of resilient cities: Whose resilience and whose city? Build. Res. Inf. 2014, 42, 191-201. [CrossRef]

22. Meyer, H.; Nijhuis, S. (Eds.) Urbanized Deltas in Transition; Technepress: Amsterdam, The Netherlands, 2014.

23. McGranahan, G.; Balk, D.; Anderson, B. The rising tide: Assessing the risks of climate change and human settlements in low elevation coastal zones. Environ. Urban 2007, 19, 17-37. [CrossRef]

24. Hallegatte, S.; Corfee-Morlot, J. Understanding climate change impacts, vulnerability and adaptation at city scale: An introduction. Clim. Chang. 2011, 104, 1-12. [CrossRef]

25. Adger, W.N. Social capital, collective action, and adaptation to climate change. Econ. Geogr. 2003, 79, 387-404. [CrossRef]

26. Heinrichs, D.; Krellenberg, K.; Fragkias, M. Urban responses to climate change: Theories and governance practice in cities of the global South. Int. J. Urban Reg. Res. 2013, 37, 1865-1878. [CrossRef]

27. Ziervogel, G.; Pelling, M.; Cartwright, A.; Chu, E.; Deshpande, T.; Harris, L.; Hyams, K.; Kaunda, J.; Klaus, B.; Michael, K.; et al. Inserting rights and justice into urban resilience: A focus on everyday risk. Environ. Urban. 2017, 29, 123-138. [CrossRef]

28. Hallegatte, S.; Green, C.; Nicholls, R.J.; Corfee-Morlot, J. Future flood losses in major coastal cities. Nat. Clim. Chang. 2013, 3, 802-806. [CrossRef]

29. Davoudi, S.; Brooks, E.; Mehmood, A. Evolutionary resilience and strategies for climate adaptation. Plan. Pract. Res. 2013, 28, 307-322. [CrossRef] 
30. Pendall, R.; Foster, K.A.; Cowell, M. Resilience and regions: Building understanding of the metaphor. Camb. J. Reg. Econ. Soc. 2010, 3, 71-84. [CrossRef]

31. Davoudi, S. Resilience, Uncertainty, and Adaptive Planning. In Governance of Climate Responsive Cities; Peker, E., Ataov, A., Eds.; Springer: Cham, Germany, 2021; pp. 9-19.

32. Sharifi, A.; Yamagata, Y. Resilience-oriented urban planning. In Resilience-Oriented Urban Planning. Lecture Notes in Energy; Yamagata, Y., Sharifi, A., Eds.; Springer: Cham, Germany, 2018; pp. 3-27. [CrossRef]

33. Aldunce, P.; Beilin, R.; Handmer, J.; Howden, M. Stakeholder participation in building resilience to disasters in a changing climate. Environ. Hazards 2016, 15, 58-73. [CrossRef]

34. Iturriza, M.; Labaka, L.; Hernantes, J.; Abdelgawad, A. Shifting to climate change aware cities to facilitate the city resilience implementation. Cities 2020, 101, 102688. [CrossRef]

35. Robinson, G.M.; Carson, D.A. Resilient communities: Transitions, pathways and resourcefulness. Geogr. J. 2016, 182, 114-122. [CrossRef]

36. Ostrom, E. Polycentric systems for coping with collective action and global environmental change. Glob. Environ. Chang. 2010, 20, 550-557. [CrossRef]

37. Jordan, A.; Huitema, D.; Van Asselt, H.; Forster, J. (Eds.) Governing Climate Change: Polycentricity in Action? Cambridge University Press: Cambridge, UK, 2018.

38. Geels, F.W.; Schot, J. Typology of sociotechnical transition pathways. Res. Policy 2007, 36, 399-417. [CrossRef]

39. Rijke, J.; van Herk, S.; Zevenbergen, C.; Ashley, R. Room for the River: Delivering integrated river basin management in the Netherlands. Int. J. River Basin Manag. 2012, 10, 369-382. [CrossRef]

40. Manohar, L.; Muthaiah, K.T. Towards Resilience in Chennai. In International Planning History Society Proceedings, Proceedings of the 17th IPHS Conference, History-Urbanism-Resilience; TU Delft, The Netherlands, 17-21 July 2016, Carola, H., Ed.; TU Delft Open: Delft, The Netherlands, 2016; Volume 3, p. 251. [CrossRef]

41. Suriya, S.; Mudgal, B. Impact of urbanization on flooding: The Thirusoolam sub watershed-A case study. J. Hydrol. 2012, 412, 210-219. [CrossRef]

42. Tanner, T.; Mitchell, T.; Polack, E.; Guenther, B. Urban Governance for Adaptation: Assessing Climate Change Resilience in Ten Asian Cities. In IDS WORKING PAPER 315; Institute of Development Studies: Falmer, UK, 2009.

43. Esther, S.; Devadas, M.D. A calamity of a severe nature: Case study-Chennai, India. WIT Trans. Built Environ. 2016, 165, 227-236.

44. Arabindoo, P. Unprecedented natures? An anatomy of the Chennai floods. City 2016, 20, 800-821. [CrossRef]

45. Joerin, J.; Shaw, R.; Takeuchi, Y.; Krishnamurthy, R. Assessing community resilience to climate-related disasters in Chennai, India. Int. J. Disaster Risk Reduct. 2012, 1, 44-54. [CrossRef]

46. Russo, M.; Amenta, L.; Attademo, A.; Cerreta, M.; Formato, E.; Remøy, H.; van der Leer, J.; Varju, V.; Arciniegas, G. REPAiR: REsource Management in Peri-Urban AReas: Going Beyond Urban Metabolism: D 5.1: PULLs Handbook; Delft University of Technology: Delft, The Netherlands, 2017. [CrossRef]

47. Murugan, P. Exclusive: Perumal Murugan on T.M. Krishna's Song in Solidarity with Chennai's Endangered Creek. The Wire. 19 January 2017. Available online: https://thewire.in/culture/t-m-krishna-ennore-creek-permual (accessed on 16 September 2021).

48. Correspondant, S. Over 1.5 Lakh Street Vendors Affected. The Hindu. 24 March 2016. Available online: https:/ / www.thehindu. $\mathrm{com} /$ news/cities/chennai/over-15-lakh-street-vendors-affected/article8023454.ece (accessed on 16 September 2021).

49. Chaitanya, S.K. Chennai's Green Cover Shrinking, Needs Structural Plan, Finds Report. The New Indian Express. 4 February 2018. Available online: http:/ /www.newindianexpress.com/cities/chennai/2018/feb/04/chennais-green-cover-shrinkingneeds-structural-plan-finds-report-1768037.html (accessed on 16 September 2021).

50. Kumar, K.P. Chennai Least Green Among Metros. The Times of India. 6 January 2011. Available online: https:/ / timesofindia indiatimes.com/city/chennai/Chennai-least-green-among-metros/articleshow/7232626.cms (accessed on 16 September 2021).

51. Aithal, B.H.; Ramachandra, T. Visualization of urban growth pattern in Chennai using geoinformatics and spatial metrics. $J$. Indian Soc. Remote. Sens. 2016, 44, 617-633. [CrossRef]

52. TNN. Chennai Has One Tree per 33 Residents. Times of India. 16 July 2018. Available online: https:/ timesofindia.indiatimes. $\mathrm{com} /$ city/chennai/chennai-has-one-tree-per-33-residents/articleshow/65001644.cms (accessed on 16 September 2021).

53. Bhattacharya, S. 'Clean Chitlapakkam' Project Launched. The Hindu. 9 June 2003. Available online: https://www.thehindu. com/todays-paper/tp-national/tp-tamilnadu/clean-chitlapakkam-lake-project-launched/article27777056.ece (accessed on 16 September 2021).

54. Ellis, R. "A World Class City of Your Own!": Civic Governmentality in Chennai, India. Antipode 2012, 44, 1143-1160. [CrossRef]

55. Arabindoo, P.G. Absent Societies: Contouring Urban Citizenship in Postcolonial Chennai; London School of Economics and Political Science: London, UK, 2008.

56. Vencatesan, J. Wastelands: Is it time to rethink? Curr. Sci. 2006, 91, 1454-1455.

57. Care Earth; City Connect. Adaptive Management Plan for the Conservation of Pallikaranai Marsh; Care Earth Trust: Chennai, India, 2010.

58. Ramakrishnan, S. Chennai's Chitlapakkam Lake Revival Model Holds Key to Fight Water Crisis. The Indian Express. 31 May 2019. Available online: https:/ indianexpress.com/article/cities/chennai/chennais-chitlapakkam-lake-revival-model-holdskey-to-fight-water-crisis-5758223/ (accessed on 16 September 2021). 
59. Swaminathan, A. R.A. Puram Counts Every Drop of Water. The Hindu. 13 July 2018. Available online: https://www.thehindu. $\mathrm{com} /$ news/cities/chennai/ra-puram-counts-every-drop-of-water/article24412441.ece (accessed on 16 September 2021).

60. Information and Resource Centre for the Deprived Urban Communities, and Housing and Land Rights Network, New Delhi. From Deluge to Displacement: The Impact of Post-flood Evictions and Resettlement in Chennai. International Network for Economic, Social \& Cultural Rights: New York, NY, USA, 2017. Available online: https:/ / www.escr-net.org/resources/delugedisplacement-impact-post-flood-evictions-and-resettlement-city-india (accessed on 16 September 2021).

61. Prasad, R. RTI Data Reveals that Only 34\% of Chennai Roads Are Flood Proof! Chennai Citizen Matters. 30 September 2019. Available online: https:// chennai.citizenmatters.in/rti-data-reveals-that-only-34-of-chennais-roads-have-storm-water-drains12075 (accessed on 16 September 2021).

62. Parkinson, J.; Mark, O. Urban Stormwater Management in Developing Countries; IWA: London, UK, 2005.

63. de Haan, F.J; Ferguson, B.C.; Adamowicz, R.C.; Johnstone, P.; Brown, R.R.; Wong, T.H. The needs of society: A new understanding of transitions, sustainability and liveability. Technol. Forecast. Soc. Chang. 2014, 85, 121-132. [CrossRef] 